\title{
PUBLIC TRANSPORT NETWORK AS A DEFINING PART IN A METROPOLITAN SYSTEM OF OPEN SPACES: METRO LINE 2 OF LIMA METROPOLITANA, PERU
}

\author{
SUSANA LÓPEZ VARELA ${ }^{1} \&$ JOAN MORENO SANZ ${ }^{2}$ \\ ${ }^{1}$ Universidad Peruana de Ciencias Aplicadas, Peru \\ ${ }^{2}$ Universitat Politècnica de Catalunya, Spain
}

\begin{abstract}
Urban mobility is a key issue in sustainable urban development policies. However, in the last few decades, the rise of urban traffic has aggravated environmental quality, spatial fragmentation, and social cohesion in metropolitan areas. Meeting commuter's needs should not be contrary to improving the quality of the environment. Public politics based on an integrated spatial planning of urban mobility and the urban fabric, following environmental principles, would contribute to make an accessible system of public spaces. The main goal of this research is to assess how a mass transport network could become the backbone of a metropolitan public space system. Integrated planning of public transport and open space system could contribute to improve indicators related to urban mobility, environmental quality and social inclusion, in unstructured environments and socially vulnerable communities. This scientific-analytic research is focused on three variables: urban mobility, urban morphology and social inclusion, and their quantitative and qualitative indicators (traffic flows, land-use patterns, air pollution, socio-economic status, public space area per capita, etc.). These indicators are tested in Metro Line 2 of Lima, currently under construction. Lima Metropolitana is one of the largest Latin-American conurbations with a population of just over 9.5 million and 22 million commuters daily. Moreover, traffic congestion is considered by residents as the city's second most important problem, despite which $75 \%$ of trips take place daily on public transport. An urban model based on unbalanced urban densities and no mixed land-use patterns, and informal transport services undermines the creation of a metropolitan open space system. An integrated spatial planning based on mobility and public space improving the future exchange nodes of Metro Line from a spatial and social point of view could contribute to reducing the impacts of urban flows, such as spatial fragmentation, social inequality and environmental pollution.
\end{abstract}

Keywords: public transport network, metropolitan open space system, Lima Metropolitana.

\section{INTRODUCTION}

Latin America and the Caribbean, with an urbanization rate of $80.3 \%$, is the developing region with the highest percentage of urban population at the global scale [1]. Two are the principles that have characterized this urbanization process since the 1990s, agglomeration and informality. First, half of the inhabitants of urban areas in the region concentrate in nuclei of more than a million, even exceeding 10 million in conurbations such as the Valley of Mexico, Sao Paulo or Lima Metropolitana. One of the opportunities of Latin American cities compared to other global conurbations is their high urban density, below than Greater London 5,600 inhabitants $/ \mathrm{km}^{2}$, but above the 685 inhabitants $/ \mathrm{km}^{2}$ of the New York TriState area. These characteristics place large Latin-American cities as key foci for social, economic, and environmental development in the region. Second, the high level of informality of cities in Latin America is notorious in housing and occupation as well as in transportation. Currently, it is estimated that $36 \%$ of the region's population resides in informal, unplanned settlements with precarious access to basic public services [2].

In this context of agglomeration and informality, mobility plays a fundamental role in the prosperity and quality of urban life in Latin America. In recent decades, the investment 
deficit in mass public transport networks has produced the proliferation of informal collective transport systems with low safety and comfort and has favored the use of private vehicles. Between 2007 and 2014, the automobile fleets in Latin-America increased by $40 \%$ while the population did so by only $10 \%$ [2]. High congestion in city centers and inefficient mobility models translate into less economic competitiveness at the regional level and also higher social and environmental costs. Socially, compulsory travels can reach $19 \%$ of the monthly household budget, making mobility an exclusion factor, not counting the investment of time in travel [3]. From an environmental point of view, the increase in negative externalities of traffic affects public health and the quality of urban spaces [1]. The dynamics of urban growth linked to the development of transport networks have not only produced quicker and greater disappearance quality urban and peri-urban open spaces [4], but also their spatial fragmentation and ecological degradation, thus hindering the incorporation of a metropolitan network of connected and accessible open spaces.

This research starts from the objectives of the New Urban Agenda [5] in favor of a morphologically compact, functionally diverse, and socially inclusive city model. The principle of transport-oriented development is taken as a reference, which on the one hand promotes - against the massive use of private vehicles - an accessible, efficient and inclusive public transport system, on the other hand contemplates the creation of networks of quality public spaces, accessible, connected and inclusive, that allow increasing urban resilience facing climate change, improving the environmental quality of cities and the health of their citizens.

Therefore, departing from the need to plan public transport and open space networks in an integrated way, the main objective is to evaluate the capacity of mass transport infrastructure as the backbone of an open space network at the metropolitan scale, and how this integration can contribute to the improvement of local mobility, open space area and social inclusion indicators. From the methodological point of view, the quantitative indicators derived from the three variables (urban mobility, open space area and social inclusion) will be evaluated, as well as their application to the route surrounds of the new Lima Metropolitana Metro Line 2 in Peru. The main novelty of this paper is to provide an integrated urban planning vision of public transport infrastructure and open space system in social and economic depressed urban areas. This scientific approach has never been considered in Peruvian spatial planning, where transportation networks and open spaces system are developed according to current situation. Urban data and graphics are also originals.

\section{CONCEPTUAL FRAMEWORK}

\subsection{Transport network system}

This research is based on the principle of sustainable mobility, defined as the set of compulsory travel aimed at guaranteeing access to basic urban services and whose satisfaction must be given in a reasonable time and cost, taking into account the impact that this movements have on the quality of life of citizens and the environment [6]. The concept of sustainable urban mobility takes a double social and environmental dimension; first, based on the principle of the Right to the City [7], since effective equality of opportunity for all citizens also depends on access to basic urban services; second, from an environmental perspective, considers the impact of mobility in the urban environment. An urban model based on the principle of sustainable mobility consists of evaluating the 
equitable distribution of the urban space of each mode of transport, affirming that the mobility space is also public space [8].

There is an interdependent relationship between urbanization processes, i.e. how urban activity is distributed throughout the territory, and the flow dynamics linked to the transport of people, goods and services [9]. The spatial materialization of this relationship between activity and mobility, or between the land's functional patterns and the transport infrastructure, will depend on each geographical, social and economic context. In addition, the design principles of the transport infrastructure - dependent on technical requirements such as the vehicle speed or the road capacity - in addition to the availability of resources, sometimes cause transport networks to act as physical barriers to the continuity of natural and urban systems [10]. However, the double nature of the space occupied by the transport infrastructure should be considered, as a node for the accumulation of flows, and as a vital, mixed and accessible urban place [11]. In short, it is imperative to understand transport infrastructure as a public space for civic interaction.

Urban planning policies based on integrating mobility and land-uses prioritize the public transportation systems as a tool to regularize the territory. Communal transportation can assimilate a high demand of users, according to its suitable safety and comfort nature. Planning a new and efficient urban model, as an alternative to car use, would imply, from a spatial point of view, a cut down in the distance between activities and a concentration of urban activities, and from a traffic perspective, can improve the quality of public transportation service by establishing an appropriate hierarchy of connections [11].

\subsection{Open space system}

Open space is defined as space located on urban land that regardless of its public or private accessibility, is not in service for an architectural structure [12], it is an unbuilt area characterized by a low level of intervention [13], with a significant amount of vegetation [14] and predominantly publicly owned.

Traditionally, open spaces in urban environments have been conceived as fragments or isolated pockets of soil not forming a connected system. Sometimes these urban voids have been the result of an intensive urbanization process that excluded inaccessible, residual spaces, while in other cases what has predominated is a formalist vision with recreational use over other types of environmental or ecological values. [15], [16]. The lack of a systemic vision of open spaces in the urban environment has triggered isolation and degradation dynamics that omit the environmental and social benefits of this ecological matrix and even deny its urban structuring role [17].

The principles of ecological sustainability, and the progressive consideration of environmental dimension in open space, helped to propose ecological networks of open spaces to serve the multiple social, territorial and environmental services [18]. The quality of these services will depend on variables such as surface, distribution and accessibility [19]. Urban communities and public administrations, aware of the social and environmental benefits of this system, have implemented open space planning policies [20]-[22] based on sustainable urban development principles [23]. Therefore, the conception of open spaces as a backbone subsystem at the urban and metropolitan scale [23] with social, environmental and economic benefits [24], should allow overcoming the isolated or fragmented vision of these spaces to be integrated under a more systemic and articulating conception. 


\section{LIMA METROPOLITANA AS A CASE STUDY}

Lima Metropolitana is located on the central Peruvian coast and extends along the western Andean slope of the Chillón, Rímac and Lurín river basins. Despite the aridity of the desert in which the city is located, the influence of the Humboldt current, and orographic altitudes reaching $850 \mathrm{~m}$ define four types of geographic units - coastline, desert, valley and mountain range - that include diverse landscapes and ecosystems. From a demographic point of view, the census population in Lima Metropolitana is 9.5 million people, and it concentrates $32.6 \%$ of the total population of Peru [25] (Figs 1 and 2). Despite being the fifth metropolis in population in Latin America, it occupies $2,819 \mathrm{~km}^{2}$, therefore its urban density $-3,563 \mathrm{hab} / \mathrm{km}^{2}$ - is significantly higher than the average values of the region [25]. The population distribution has changed significantly overtime, especially after growth bursts since the 1980s when poverty, and later armed conflict, triggered immigration from the interior to settlements in the peripheries. As a consequence, Lima Metropolitana currently follows two antagonistic urban development patterns: on one hand, an extensive peripheral growth of an informal nature based on agricultural land, wasteland or of high landscape value - and that constitutes $27.5 \%$ of the population urban area of Lima and $36.1 \%$ of the Department of Callao [25] - and on the other hand, the densification of urban areas using high-rise residential buildings, with overcrowding rates reaching $52 \%$ - in the case of Gamarra, La Victoria district [26].

\subsection{Massive transport networks in Lima Metropolitana}

The first metropolitan mass transport system in Lima dates from 1878 with the inauguration of the animal-drawn tram between the Rimac neighborhood and the Parque de la Exposicion park, followed by the implementation of an electric tram in 1904 that connected Lima and the Port of Callao and with the districts of Miraflores and Chorrillos, then resort towns. The tram had four lines operating until the early 1960s, when the formal public transport service companies (tram and buses) went bankrupt as a consequence of the

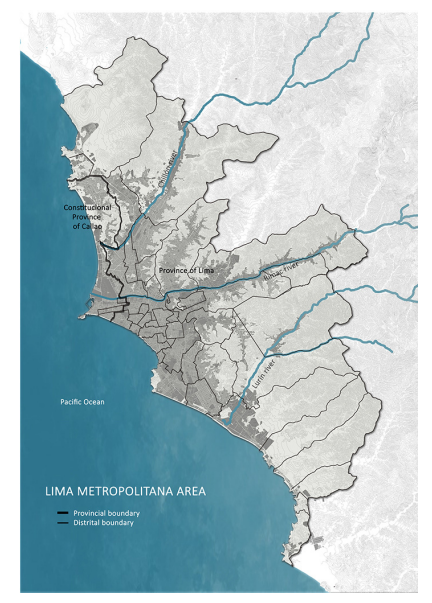

Figure 1: Lima Metropolitana: Physical context. (Source: Prepared by Carlos Guardia Brown based on data from the National Geographic Institute (IGN), National Institute of Statistics and Informatics (INEI) and the National Water Authority (ANA).) 


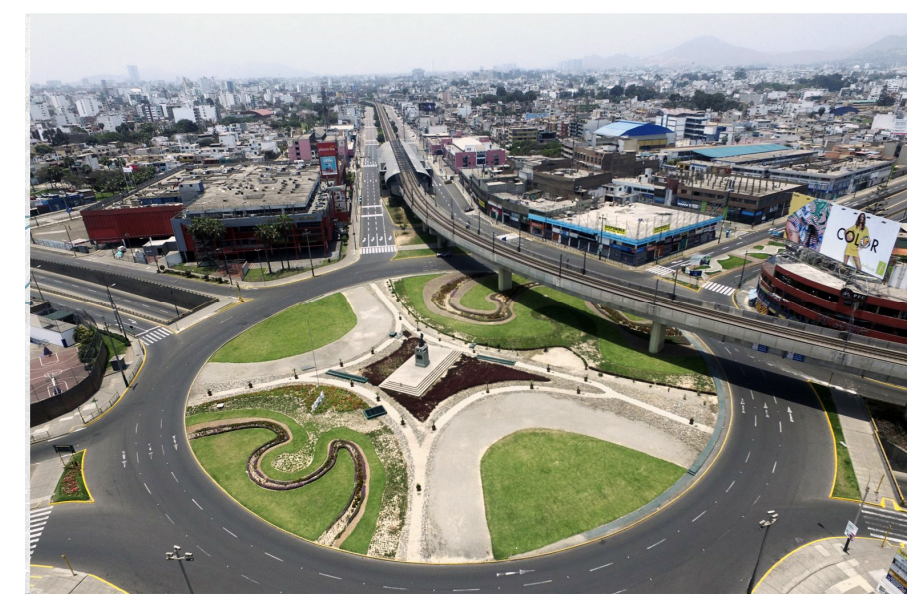

Figure 2: Higuereta roundabout view. (Source: ANDINA/Oscar Farje, Agencia Peruana de Noticias Andina, 2017.)

proliferation of the informal transport supply, which would reach rates of $90 \%$ in the 1980 s [27]. However, the history of mass public transport in Lima Metropolitana suffered a turning point with the approval in 1991 of the Decree 651 for the establishment of free competition for urban and interurban transport rates that liberalized public transport. This Decree, which allowed any citizen to provide service with any type of vehicle and with a deregulated rate system, has led to an informal transport rate among the highest in the region: for example, in Lima there are 28 taxis/1,000 inhabitants when in Latin America the average is nine [28].

Adding to this conditions the unrestricted importation of used vehicles - bearing a highly polluting and uncomfortable fleet - and poor traffic management [27], positions Lima Metropolitana, with its 22.3 million daily commuters, among the Latin American conurbations with the highest level of congestion with a prospected increase of $50 \%$ in the next five years [29]. Its social consequences are reflected in the time invested in transportation: $25 \%$ of Lima residents spend more than 2 hours on their daily compulsory trips [30]; the environmental consequences are evident in the increase in air pollution: Lima was the second Latin-American city with the highest concentration index of $\mathrm{PM}_{10}\left(88 \mu / \mathrm{m}^{3}\right)$ [31], and $30 \%$ of the carbon footprint comes from transportation [32]. These data lead to consider transportation as the second biggest problem that affects the quality of life of the population, and pollution emitted specifically by vehicles, the main environmental problem for more than $70 \%$ of its citizens [30]. However, paradoxically, two particularities stand out: Lima Metropolitana is one of the urban systems with the lowest motorization index in Latin America: 108 vehicles/1,000 inhabitants - Santiago has 172 and Buenos Aires 335 [26] - and a high $75 \%$ of daily trips are made via public transport [29].

In 2012 the ordinance No. 1613 was approved creating the "Lima Metropolitana Integrated Public Transport System, SIT" with the aim of reordering the mass transportation network and creating an integrated, accessible, efficient and environmentally friendly system that improves the quality of life and urban mobility of the metropolis. The SIT is a massive public transport system operated by the Urban Transport Authority (ATU) under the Ministry of Transport and Communications, and whose principles are the promotion of sustainable mobility and integration with territorial and environmental 
planning (Fig. 3). It is made up of the High Capacity Segregated Corridors (COSAC) which includes the Metropolitano Bus Rapid Transit service and its Complementary Bus Corridor system running on dedicated or mixed lanes (operated by Pro-transporte), and the network of railway passenger transport, the Lima and Callao Metro, which currently has one operating line, Line 1 (2011).

\subsection{Open space system in Lima Metropolitana}

Although the concept of green space as a legal figure was not introduced into Lima's urban planning until the approval of the 1949 Pilot Plan [33], partial systematization and classification efforts were carried out public space network of parks, tree-lined avenues and social sidewalks during the first half of the 20th century [34], including a first proposal to connect these spaces through a belt of urban parkways [35]. The first study that proposed the establishment of a hierarchical, trans-scalar and connected system of green areas was carried out in 1958; given the deficit of green areas in some densely populated sectors of the city, a "Recreational Plan for Lima" was opted for, which, akin a park system, incorporated the network of tree-lined avenues, parkways and streets based on human routes, and included a new category of "suitable land" (public plots on vacant lots, built land with buildings in a precarious state, private parks in disuse, etc.) [36]. Subsequently, the Lima Callao Metropolitan Development Plan, PLANDEMET (1968-1980) defined, although without repercussion, the creation of a connected and hierarchical system of green areas and corridors based on their size and potential use [37]. Finally, the Open Spaces and Ecological Infrastructure Plan (PEIAE), an integral part of the PLAM 2035 (2014) - neither have been approved - conceived the open space network as a system, which, together with the transport and public equipment network, will form an environmental integral network of territorial-metropolitan scale (Fig. 4). Moreover, the PEIAE included for the first time the concept of "open space", "spaces for public use or with potential to be so, owned and managed by public and/or private entities, that may be located in an urban area, an area of urban expansion or a non-developable area", thus overcoming previous more restrictive terms such as public space, free space or green space.

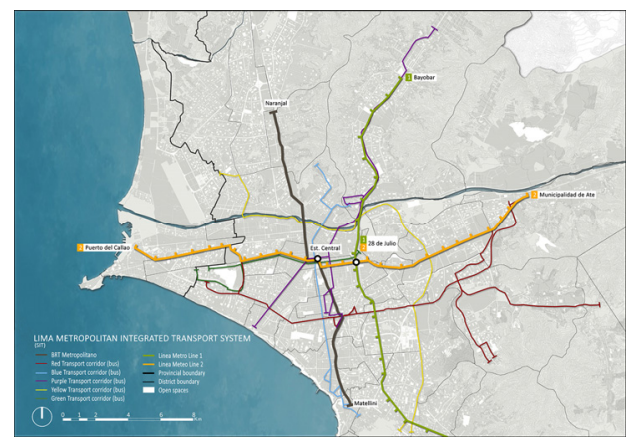

Figure 3: Integrated Transport System (SIT) of Lima. (Source: Prepared by Carlos Guardia Brown based on the Transport and Communications Ministry (MTC) and ATU concessions.)

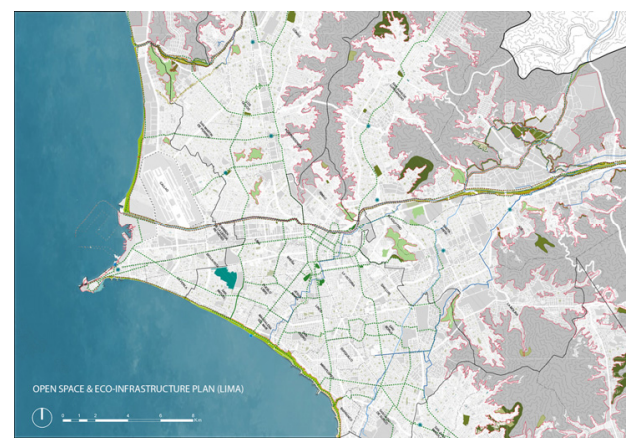

Figure 4: Lima's open space and ecological infrastructure system. (Source: PEAIE, 2014.) 
Currently, green area per inhabitant in Lima Metropolitana is $3.36 \mathrm{~m}^{2}$ per inhabitant [38], far below the $9 \mathrm{~m}^{2}$ recommended by the World Health Organization (WHO). Despite this deficit situation, the low quality and quantity of these spaces rank low in problem importance for Lima and Callao citizens - with a percentage of $8 \%$ and $13 \%$ respectively in Lima Metropolitana [30]. This relative disregard is also problematic given that a system of connected open spaces and biodiversity, capable of integrating both natural spaces and urban voids, is one of the main factors for mitigating the negative effects of urban traffic.

\section{METHODOLOGY. THE METRO LINE 2}

The Lima and Callao metro network was approved by Supreme Decree No. 059-2010-MTC with the aim of securing railway land for five lines, to which a sixth was incorporated in 2013. Currently, only Line 1 (2011) is operational, it runs in a north-south direction between the districts of Villa El Salvador and San Juan de Lurigancho with a viaduct length of $37 \mathrm{~km}$ and an annual demand of 126 million passengers [30]. Demand grew quickly reaching in just four years the estimate for 2035: 340,000 passengers/day. This, added to the precariousness of the connections in the east-west direction, made necessary to include Line 2 in the Multi-Annual Strategic Plan for the Transport and Communications Sector 2012-2018, with the aim of "managing the integrated mass transport system of passengers from Lima-Callao through the Lima Metro". The project, currently underway, includes the construction of a $27.2 \mathrm{~km}$ long tunnel between the Ate and Cercado del Callao districts, as well as a branch of the future Line 4 in direction to the Jorge Chávez International Airport. It is estimated that the beneficiary population will amount to 2.4 million people $-35 \%$ of the total population - and the demand will reach 600,000 passengers/day [39]. With the goal of being a safe, fast, inclusive, and environmentally responsible transport service, connecting high-density and peripherally located areas, the implementation of the Line would reduce private mobility in the city by $10 \%$ [40]. Its benefits will be translated, not only to sustainable urban mobility, but also to environmental quality, making the Line 2 of the Metro an opportunity to create a connected and inclusive open space system at the metropolitan scale.

\subsection{Methodology}

The study area corresponds to the delimitation of Lima Metropolitana. This conurbation comprises a total of fifty districts distributed between the Province of Lima (43 districts) and the Constitutional Province of Callao (seven districts), provinces which have departmental autonomy due to their status as part of the State capital, with the respective municipalities assuming departmental government functions. Therefore, transportation and urban planning are the responsibility of the provincial municipalities, while interurban ground transport falls under the authority of the Ministry of Transportation and Communications (MTC); at the metropolitan level, the Urban Transport Authority for Lima and Callao (ATU), an organization dependent on the MTC, is responsible for the management of the Integrated Transport System (SIT) since 2018. At the local level, the management and control of traffic is a competence shared also with the districts.

Methodologically, the collection of data on Lima Metropolitana has been carried out from the exhaustive review of official sources - such as current and proposed management plans - and statistical data updated by the competent administrations, and through a cartographic survey of Lima Metropolitana, that allows a comparative analysis to be carried out in the surroundings of Metro Line 2, taking as a service area a radius of $500-1,000 \mathrm{~m}$ around future stations. In accordance with the objectives of the research work, the 
quantitative indicators have been classified into three groups: urban mobility, open spaces and social inclusion. For the indicators for which no detailed data were available by station, statistical data has been extrapolated from the ten districts through which the route of Line 2 runs.

\subsubsection{Urban mobility}

Urban mobility is evaluated on the basis of three basic indicators: the level of motorization of the population, the modal distribution between the different transport systems, and the distribution of urban activity that conditions compulsory travel.

Every day a total of 22.3 million trips are produced in Lima Metropolitana, 16.9 million in motorized vehicles, of which $10.8 \%$ in Lima and $11.1 \%$ in Callao are made in private vehicles [30]. There is a correspondence between the increase in the car fleet and the congestion of the road network, which in the case of Lima is one of the highest in the region after Bogotá. However, Lima Metropolitana has a motorization rate of 108 vehicles per 1,000 inhabitants, very far from that of other metropolises such as Buenos Aires (335) [41]. The key to the urban congestion of Lima Metropolitana is not then in the motorization rate, but in the modal distribution: $75 \%$ of the movements of the metropolis are made by public transport (Fig. 5) but preferably in means such as minivans ("combi") (30\% in Lima and $40 \%$ in Callao) or bus (30\% in Lima and $24 \%$ in Callao), with a high level of informality. The Integrated Transport System (SIT) barely reaches $8 \%$ of the share in the modal distribution [30].

One of the aspects that determines compulsory mobility in Lima Metropolitana is the land's functional pattern (Fig. 6), i.e. the distribution of urban activities in the territory. In this sense, the urban land area destined for residential uses accounts for $82.4 \%$ of the total, while economic activities such as industry and commerce barely reach $4 \%$. In the surrounds of the future Metro Line 2, the proportions of land uses are significantly different. Exclusively residential uses make up $56.1 \%$, while the area allocated to productive activity reaches $10.8 \%$ of the total. Another significant fact is that the area for recreational use or public services is three times the average of Lima Metropolitana, representing more than $30 \%$ of the total. All these data reinforce the character of this axis as a functionally diverse and equipped urban connector.

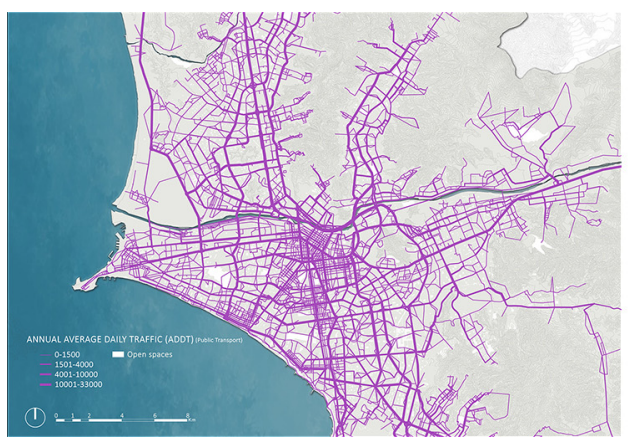

Figure 5: Average intensity of public transport per hour; Metro Line 2. (Source: Prepared by Carlos Guardia Brown based on PLAM 2035 and $A T U$.)

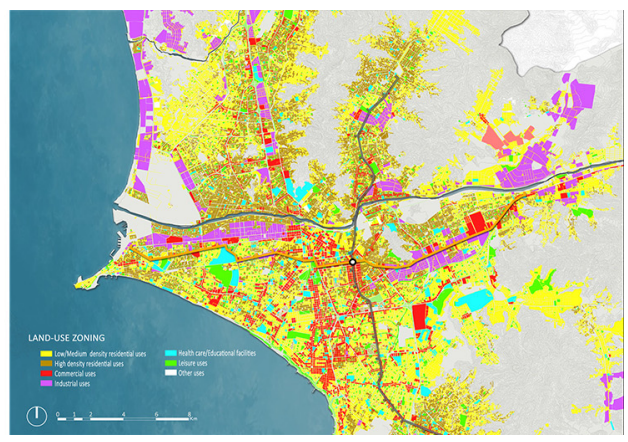

Figure 6: Distribution of land uses in Lima Metropolitana. (Source: Prepared by Carlos Guardia Brown based on PLAM 2035 and ATU.) 


\subsubsection{Open space}

Considering that green areas provide citizens with social and environmental services based on their area, distribution and accessibility [19], the open space system has been evaluated based on indicators such as green area per inhabitant - related to urban density - its accessibility and its distribution in the territory.

To help mitigate some problems of large cities such as air pollution, social disintegration or lack of public safety, standards have been established for the provision of green area per inhabitant [42], such as the $9 \mathrm{~m}^{2}$ recommended by the World Health Organization [17]. However, these parameters can be quite demanding for certain contexts, which must be adjusted to the geographical particularities, extension, population density and socioeconomic diversity of the city. In the South American Region, the threshold of $8 \mathrm{~m}^{2}$ of public green area per inhabitant is usually used [19].

In the case of Lima Metropolitana, the green area per inhabitant is $3.36 \mathrm{~m}^{2}$. In the case of the Line 2, despite the fact that all the districts exceed by far the average density of 3,563 inhabitants $/ \mathrm{km}^{2}$ (Fig. 7), none reach $5 \mathrm{~m}^{2}$; even districts with densities much higher than the average, the cases of Breña with 23,566 inhabitants $/ \mathrm{km}^{2}$ and Sta. Anita with 22,640 inhabitants $/ \mathrm{km}^{2}$, have considerably lower green area per inhabitant than the average (Fig. 8), $1.01 \mathrm{~m}^{2}$ and $2.3 \mathrm{~m}^{2}$ respectively [30]. On the other hand, regarding accessibility to green areas, defined as the degree or level of access that people have in a given time and place to open spaces, [22] indicates that $25.1 \%$ of the population of Lima and $12.3 \%$ of Callao lives more than five blocks (500 meters) away from a park. This percentage reaches $30 \%$ in Lima and 40.6\% in Callao for social sectors with a socioeconomic level of D/E [29].
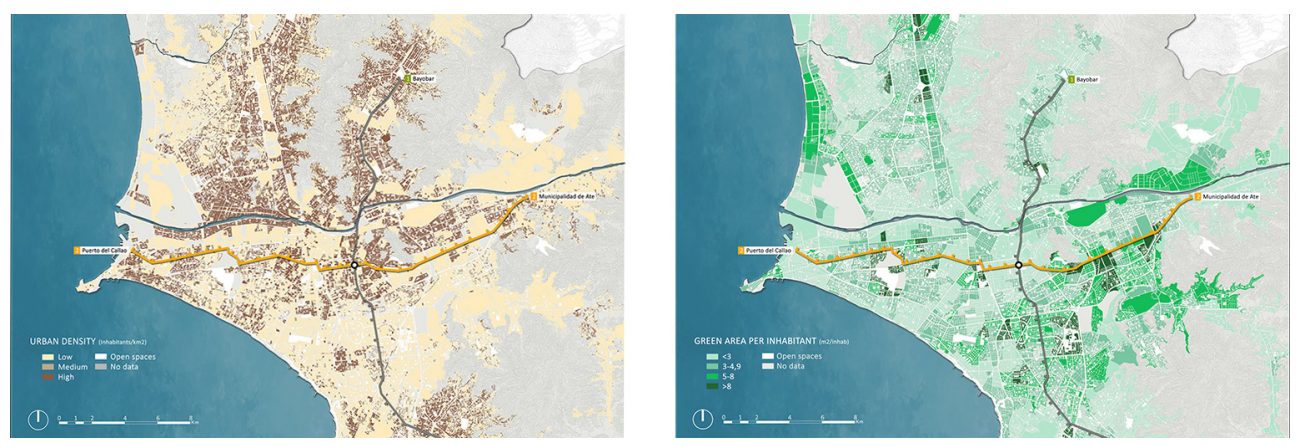

Figure 7: Urban density (inhabitants $/ \mathrm{km}^{2}$ ) in Figure 8:

Green area $\left(\right.$ in $\left.\mathrm{m}^{2}\right)$ per

Lima Metropolitana. (Source:

Prepared by Carlos Guardia

Brown based on INEI 2016 and

$A T U$.)

inhabitant in Lima

Metropolitana. (Source:

Prepared by Carlos Guardia

Brown based on INEI 2016 and $A T U$.

\subsubsection{Social inclusion}

To assess the level of social inclusion of the new Line 2 of the Lima Metro, the geographical distribution of the social strata along the route will be taken into account. This indicator reports on three characteristics: demographic - considers the social composition of households based on age and income - educational - attaining to the educational level of the head of the family and the illiteracy rate - and finally housing equipment [25]. 
Inclusion and social cohesion are measured based on equal opportunities for citizens to participate in city life, which in spatial terms implies universal access to the entire urban geography [43]. A first approximation to the socioeconomic structure of the urban community implies, in the Peruvian context, attending to the indicators on the social strata in Lima Metropolitana (Figs 9 and 10), about 30\% of Lima's population and $50 \%$ of Callao belong to the most disadvantaged social strata $(\mathrm{D} / \mathrm{E})$, while the $\mathrm{A} / \mathrm{B}$ strata do not reach $15 \%$ in the two provinces [30]. In the environment of the future Line 2 these data are significantly accentuated: the population belonging to the A/B strata represent $3.4 \%$ of the total while the $\mathrm{D} / \mathrm{E}$ strata $65 \%$, with an average level of $41.3 \%$. These percentages are especially relevant if the population density is taken into account, as in this sector it is higher than the average for Lima Metropolitana and that the population over 45 years of age doubles the average of $6.7 \%$.

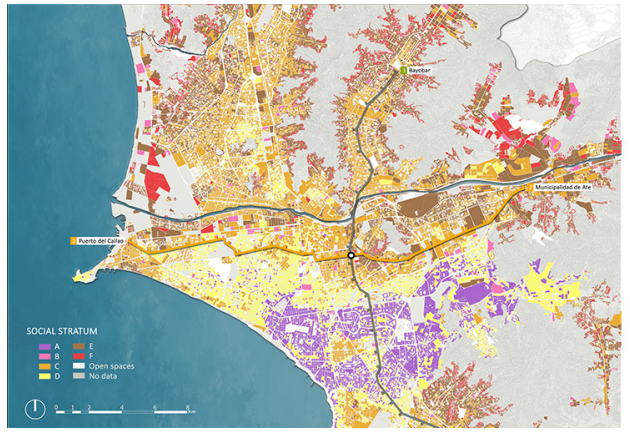

Figure 9: Distribution of social strata in Lima Metropolitana. (Source: Prepared by Carlos Guardia Brown based on data from INEI 2016 and $A T U$.)

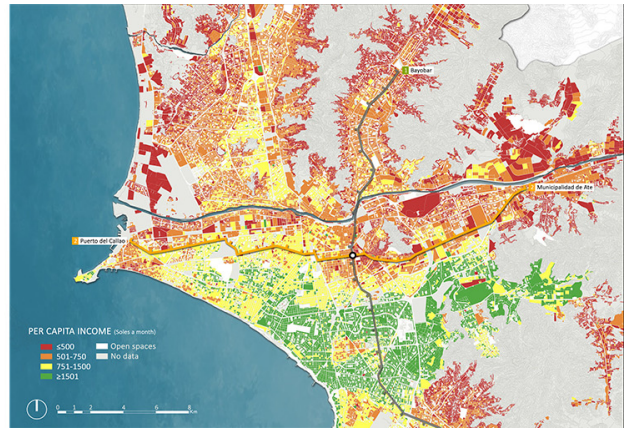

Figure 10: Income per inhabitant in Lima Metropolitana. (Source: Prepared by Carlos Guardia Brown based on data from INEI 2016 and ATU.)

\section{CONCLUSIONS}

The lack of integration between the massive public transport network and open spaces in Lima Metropolitana is a fact. Neither one is adequately conceived as a hierarchical and connected system.

Despite the high percentage of trips by public transport and the low rate of private motorization, the Integrated Transport System is insufficient for the mobility demand that the metropolis requires. To this must be added the high informality rate of the metropolis public transport system, poor management and the lack of integration between the different types of public transport; all this has an impact on transport times, as well as on comfort and safety conditions.

The great weakness in the conception of open spaces throughout the different plans, as well as the evident deficiency in the regulations that govern them, has resulted in a set of good intentions that fail to generate integrative and systemic proposals capable of generating an interconnected network of open spaces in Lima Metropolitana. For this reason, it is necessary to unify definitions, sizes, typologies, uses, in order to define clear, efficient and realistic indicators that encourage the creation and connection of these spaces. Moreover, the great diversity of actors involved in its creation, administration and maintenance, with autonomous, shared or overlapping competences, represent a handicap 
when it comes to create, maintain and efficiently manage open space systems. Therefore, the inter-institutional and coordinated management of the different tutelary entities of open spaces in Lima Metropolitana is an essential requirement, in addition to urgent strategies for the selection and design of new open spaces, as well as clear and efficient criteria in prioritizing areas for enabling these.

Under this scenario, the construction of the new Metro Line 2 can be an opportunity to integrate the massive public transport network and provide a structure for an inclusive and accessible system of open spaces.

\section{ACKNOWLEDGEMENTS}

This research has received financial support from the Annual Research Incentive Competition convened by the Universidad Peruana de Ciencias Aplicadas (Peru), through the project "Mass public transport network as a backbone element of the metropolitan open space system, the Lima Metro as a case study" led by Professor Susana López; Ii has also obtained the Ibero-America Santander Research Scholarship 2019 for the project "The public transport network as a backbone element of the system of environmentally sustainable and socially inclusive urban spaces: the case of Lima Metro, Peru", with Professor Joan Moreno as grantee. Likewise, we would like to especially thank the student of Geography and Environment, Carlos Guardia Brown, for his contribution to the analysis of cartographic data and graphic expression of the figures included in the document.

\section{REFERENCES}

[1] BBVA (Banco Bilbao Vizcaya Argentaria) Research, Urbanización en América Latina, BBVA Research: Madrid, 2017.

[2] CAF, Banco de Desarrollo de América Latina, Crecimiento urbano y acceso a oportunidades: un desafio para América Latina, CAF: Buenos Aires, 2017.

[3] Cervero, R., Transport Infrastructure and the Environment: Sustainable Mobility and Urbanism, Bandung Institute of Technology: Bandung, 2013.

[4] Astorkiza, I. \& Ferrero, A.M., Expansión urbana y sostenibilidad: una dicotomía difícil de reconciliar. Revista española de control externo. Tribunal de cuentas: Madrid, 40, pp. 47-78, 2012.

[5] UN (United Nations), New Urban Agenda - Habitat III. ONU: Quito, 2017.

[6] Gencat, Ley 009/2003, de 13 de junio, de la movilidad. Diario Oficial de la Generalitat de Catalunya, 13 Jun. 2013, no. 3913, pp. 1-16.

[7] Lefebvre, H., Le Droit à la ville, Du Seuil: París, 169 pp., 1968.

[8] Borja, J., La ciudad conquistada, Alianza Editorial: Madrid, 2003.

[9] Calthorpe, P. et al., The Next American Metropolis: Ecology, Community and the American Dream, Princeton Architectural Press: New York, 1993.

[10] Herce, M. \& Magrinyà, F., Construcció de la ciutat I xarxces d'infraestructures, Edicions UPC: Barcelona, 2004.

[11] Bertolini, L., Curtys, C. \& Renne, J. Transit Oriented Development: Making it Happen, Ashgate: Farnham, UK, 2009.

[12] Eisenberg, B. et al., Estrategia de Infraestructura ecológica de Lima, Instituto de Planificación de Paisaje y Ecología, Universidad de Stuttgart: Stuttgart, 2014.

[13] Maruani, T. \& Amit-Cohen, I., Open space planning models: A review of approaches and methods. Landscape and Urban Planning, 81, pp. 1-13, 2007.

[14] Jim, C. \& Chen, W.Y., Comprehensive greenspace planning. Landscape and Urban Planning, 64, pp. 95-116, 2003. 
[15] Feira, J.N. \& Santiago, J., Funciones ecológicas del espacio libre y planificación territorial en ámbitos metropolitanos. Perspectivas teóricas y experiencias recientes en el contexto español. Revista electrónica de geografía y ciencias sociales, Universidad de Barcelona: Barcelona, vol. XIII, 299 pp., 2009.

[16] Riveros, A. et al., Infraestructura verde urbana: tipos, funciones y oportunidades para el desarrollo de corredores verdes urbanos en Santiago de Chile. Ciudad y calidad de vida. Indagaciones y propuestas para un habitar sustentable, Carbonel Ed.: Santiago de Chile, USACH, pp. 93-107, 2015.

[17] UN (United Nations), Habitat III Issue Papers 3 - Safer Cities, ONU: New York, 2015.

[18] Mallarach, J.M. \& Marull, J., La conectividad ecológica en la planificación y la evaluación estratégica: Aplicaciones en el área metropolitana de Barcelona. Ciudad y Territorio: Estudios Territoriales, 147, pp. 41-60, 2006.

[19] PEIAE (Plan de Espacios Abiertos e Infraestructura Ecológica), Municipalidad Metropolitana de Lima y Servicio de Parques de Lima: Lima, 2014.

[20] McMahon, E.T. \& Benedict, M.A., Green infrastructure. Planning Commissioners Journal, 37, pp. 4-7, 2000.

[21] Barbosa, O. et al., Who benefits from access to green space? Landscape and Urban Planning, 83, pp. 187-195, 2007.

[22] Figueroa, I., Conectividad y accesibilidad de los espacios abiertos urbanos en Santiago de Chile. Instituto de Estudios Urbanos y Territoriales, Pontificia Universidad Católica de Chile: Santiago de Chile, Tesis del grado de Magister en Asentamientos Humanos y Medio Ambiente, 2009.

[23] Cruz, J., Oliveira de, G. \& Ramos, J.S., El Espacio libre en la planificación territorial: análisis comparado de las áreas metropolitanas de España. Ciudad y territorio. Estudios territoriales, 193, pp. 401-416, 2017.

[24] Vásquez, A., Infraestructura verde, servicios ecosistémicos y sus aportes para enfrentar el cambio climático en ciudades. Revista de Geografia Norte Grande, 63, pp. 63-86, 2016.

[25] INEI (Instituto Nacional de Estadística e Informática), Crecimiento y distribución de la población, INEI: Lima, 2018.

[26] PRDCLM, Plan Regional de Desarrollo Concertado de Lima 2012-2025, Municipalidad Metropolitana de Lima: Lima, 2012.

[27] Alegre, M., Transporte urbano: ¿cómo resolver la movilidad en Lima y Callao? Centro de Investigación de la Universidad del Pacífico: Lima, 2016.

[28] Instituto Peruano de Administración Municipal, Report. IPAM: Lima, 2009.

[29] Lima Cómo Vamos, Encuesta Lima como vamos 2018. IX Informe de percepción sobre calidad de vida en Lima y Callao, Lima Cómo Vamos: Lima, 2018.

[30] Lima Cómo Vamos, Lima y Callao según sus ciudadanos. X Informe urbano de percepción sobre la calidad de vida en la ciudad, Lima Cómo Vamos: Lima, 2019.

[31] WHO, Global urban ambient air pollution database (update 2016). www.who.int/phe/ health_topics/outdoorair/databases/cities/en/. Accessed on: 17 May 2020.

[32] ITF (International Transport Forum), The Carbon Footprint of Global Trade: Tackling Emissions from International Freight Transport, ITF: Paris, 2016.

[33] Ortiz, R.C., Plan Piloto de Lima 1949. Significación histórica de una vieja utopía, Universidad Nacional de Ingeniería: Lima, 2012.

[34] Ludeña, W., Lima y la cuestión del espacio público en su dimensión urbanística. Exploraciones 1990-2011. EST. Espacio, Sociedad y Territorio, 1, pp. 93-118, 2011.

[35] Montero, C., El espacio libre. Revista el arquitecto peruano, 2(6), 1938. 
[36] Guerra, T.M., Estructura y tendencias de las áreas verdes en normas y planes del período 1949-1990, en el contexto de la renovación urbana. El caso de Lima, Universidad Nacional de Ingeniería: Tesis de Maestría, Lima, 2012.

[37] PLANDEMET, Plan de Desarrollo Metropolitano de Lima-Callao 1990-2010, Municipalidad Metropolitana de Lima: Lima, 1992.

[38] Lima Cómo Vamos, Evaluando la gestión en Lima y Callao. VIII Informe de resultados sobre calidad de vida, Lima Cómo Vamos: Lima, 2017.

[39] Sobrevilla, J.H., Metro de Lima Linea 2, Universidad Nacional Mayor de San Marcos, Universidad del Perú: Lima; 2016.

[40] PLAM, Plan Metropolitano de Desarrollo Urbana de Lima y Callao 2035, Municipalidad Metropolitana de Lima: Lima, 2014.

[41] CAF, Crecimiento urbano y acceso a oportunidades: un desafio para América Latina, CAF: Buenos Aires, 2017.

[42] Flores-Xolocotzi, R., Una reflexión teórica sobre estándares de áreas verdes empleados en la planeación urbana. Economía, Sociedad y Territorio, 54, pp. 491522, 2017.

[43] Miralles, C., Transporte y territorio urbano: del paradigma de la causalidad al de la dialéctica. Documents d'Anàlisi Geogràfica DAG, Universitat Autònoma de Barcelona: Barcelona, pp. 107-120, 2002. 